\title{
PLYNNOŚĆ PRZY WYCENIE AKCJI NA GIEŁDZIE PAPIERÓW WARTOŚCIOWYCH W WARSZAWIE
}

\section{WPROWADZENIE}

Giełda Papierów Wartościowych w Warszawie jest istotnym elementem polskiego systemu finansowego, odgrywającym duże znaczenie w procesie finansowania przedsiębiorstw. Przez 25 lat swego funkcjonowania stała się największym parkietem w Europie Środkowo-Wschodniej. Aby mogła dobrze wypełniać swoją rolę w gospodarce, niezbędna jest jej efektywność operacyjna, alokacyjna oraz informacyjna. Decydujący wpływ na ich poziom wywiera płynność notowanych na niej instrumentów, która stanowi czynnik na tyle ważny dla emitentów i inwestorów, że bywa wręcz określana jako produkt oferowany przez rynek giełdowy ${ }^{1}$.

Instrument finansowy określa się mianem płynnego, jeśli można go sprzedać stosunkowo szybko po cenie zbliżonej do rynkowej. Z kolei za płynny rynek można uważać rynek, który jest ciagły, co oznacza, że niemal każda liczba akcji może zostać natychmiast kupiona lub też sprzedana, oraz rynek, na którym inwestor zawsze może kupić lub sprzedać niewielką liczbę akcji po cenie bliskiej aktualnej cenie rynkowej, natomiast znaczną ich liczbę może kupować lub sprzedawać w dłuższym okresie po cenach, których przeciętna wartość nie różni się nazbyt od ceny rynkowej. Płynność nie oznacza więc możliwości zawierania transakcji o dużym wolumenie w krótkim przedziale czasowym bez znacznej zmiany ceny².

Płynność ma znaczenie zarówno na poziomie makro-, jak i mikroekonomicznym. Ze względu na swój związek z kosztami transakcyjnymi może wpływać na stopę zwrotu z kapitału oraz na wycenę spółek, a więc na czynniki o kluczowym znaczeniu dla podmiotów zaangażowanych na rynku giełdowym. Znaczenie płynności przy wycenie instrumentów finansowych zaczęło być dostrzegane w latach osiemdziesiątych XX w. W 1986 r. Yakov Amihud i Haim Mendelson przedstawili teoretyczny model opisujacy jej wpływ na ceny aktywów oraz poparli go wynikami analizy empirycznej dotyczącej rynku amerykańskiego ${ }^{3}$. Od tego momentu nastapił wzrost liczby modeli wyceny uwzględniających zarówno poziom płynności, jego wahania, jak i ryzyko płynności.

1 J. Deryło, W. Nawrot, W. Rozłucki, Przyszłość Warszawskiej Giełdy Papierów Wartościowych, Centrum Analiz Społeczno-Ekonomicznych, Warszawa 2003.

${ }^{2}$ M. Doman, Mikrostruktura gietd papierów wartościowych, Wyd. UEP, Poznań 2011.

${ }^{3}$ Y. Amihud, H. Mendelson, Asset pricing and the bid-ask spread, „Journal of Financial Economics" 17,1986 , s. 223-249. 
Niejednokrotnie przyjmują one formę standardowych modeli wyceny, jak na przykład CAPM, czy trójczynnikowy model Famy i Frencha i sa dodatkowo wzbogacone o jedną z wielu dostępnych miar płynności.

Trójczynnikowy model Famy i Frencha był aplikowany do danych pochodzacych z polskiego rynku giełdowego. Anna Czapkiewicz i Iwona Skalna badały jego przydatność w różnych fazach cyklu giełdowego i stwierdziły, że jest on użyteczny przy wycenie aktywów w okresie hossy, jednak nieprzydatny w okresie bessy ${ }^{4}$. Monika Mościbrodzka w swojej analizie skupiła się na ocenie stabilności czynników modelu, natomiast Leszek Czapiewski, wykorzystując metodę analizy zdarzeń, przeanalizował niedoskonałości przy wycenie aktywów dokonanej za pomocą tego modelu ${ }^{5}$, które wynikały z cech fundamentalnych poszczególnych spółek ${ }^{6}$. Trójczynnikowy model Famy i Frencha został wykorzystany również w pracy Adama Zaremby, który oprócz niego posłużył się modelem czteroczynnikowym Carharta wzbogaconym o zmienna, którą jest momentum ${ }^{7}$. Z kolei Leszek Czapiewski sięgną po pięcioczynnikowy model Famy i Frencha, będący najnowszą modyfikacją modelu wyceny zaproponowaną przez tych dwóch naukowców. Oprócz trzech pierwotnych czynników został on wzbogacony o rentowność operacyjną kapitału własnego oraz przyrost majątku spółki

Celem tego artykułu jest oszacowanie trójczynnikowego modelu Famy i Frencha dla najnowszych danych pochodzacych z Giełdy Papierów Wartościowych w Warszawie, wzbogacenie go o dodatkowa zmienną objaśniająca, która jest wybrana miara płynności oraz weryfikacja hipotezy zakładającej, że poziom płynności ma znaczenie przy wycenie akcji notowanych na niej spółek. Za miarę płynności przyjęto wskaźnik przedstawiony przez Yakova Amihuda w pracy z 2002 r. - ILLIQ, który jest obliczany jako iloraz wartości bezwzględnej stopy zwrotu danej spółki i wyrażonego wartościowo wolumenu obrotu jej akcjami ${ }^{9}$.

W pierwszej części artykułu przedstawiono pokrótce wymiary płynności oraz wskazano miary wykorzystywane do określenia jej poziomu. W kolejnej omówiono sposób, w jaki płynność aktywów może wpływać na koszty transakcyjne i poprzez to na stopę zwrotu z instrumentu finansowego. Następnie przedstawiono zarys badania empirycznego - omówiono dane wykorzystane przy obliczeniach, wybraną miarę płynności oraz przedstawiono specyfikację modelu ekonometrycznego. Badanie empiryczne przeprowadzono na podstawie notowań 87 spółek notowanych nieprzerwanie na Giełdzie Papierów Wartościo-

\footnotetext{
${ }^{4}$ A. Czapkiewicz, I. Skalna, Użyteczność stosowania modelu Famy i Frencha w okresach hossy $i$ bessy na rynku akcji GPW w Warszawie, „Bank i Kredyt” 42, 2011, s. 61-80.

${ }^{5}$ M. Mościbrodzka, Stabilność czynników ryzyka w modelu Famy-Frencha wyceny kapitału, „Zeszyty Naukowe Uniwersytetu Szczecińskiego. Finanse, Rynki Finansowe, Ubezpieczenia” 2014, nr 66, s. 305-319.

${ }^{6}$ L. Czapiewski, Model CAPM i trójczynnikowy model Famy-Frencha $w$ analizie zdarzeń na polskim rynku kapitałowym, „Zeszyty Naukowe Uniwersytetu Szczecińskiego. Finanse, Rynki Finansowe, Ubezpieczenia" 2015, nr 73, s. 609-620.

${ }^{7}$ A. Zaremba, Efekty wartości, wielkości i momentum a wycena aktywów na polskim rynku akcji, ,Finanse” 2015, nr 1, s. 111-143.

${ }^{8}$ L. Czapiewski, Wykorzystanie pięcioczynnikowego modelu Famy-Frencha na polskim rynku kapitałowym, „Zeszyty Naukowe Uniwersytetu Szczecińskiego. Finanse, Rynki Finansowe, Ubezpieczenia" 2016, $\mathrm{nr}$ 82, s. 71-83.

${ }_{9}$ Y. Amihud, Illiquidity and stock returns: cross section and time-series effects, „Journal of Financial Markets" 5, 2002, s. 31-56.
} 
wych w Warszawie w latach 2000-2017. Obliczenia przeprowadzono na podstawie miesięcznych stóp zwrotu z akcji analizowanych spółek oraz indeksu WIG, rocznych wartości wskaźnika cena do wartości księgowej oraz rocznych danych dotyczących wartości spółek. Powyższe dane zaczerpnięto z serwisu Stooq. Dodatkowo wykorzystano oprocentowanie polskich rocznych bonów skarbowych z bazy Thomson Reuters. Zakres czasowy analizy ograniczono do lat 2008-2017. Wyniki oszacowań zostały przedstawione w końcowej części artykułu.

\section{WYMIARY I MIERNIKI PEYNNOŚCI}

Płynność rynkowa jest pojęciem bardzo złożonym. Można wyróżnić jej trzy zasadnicze wymiary - głębokość, naprężenie oraz sprężystość określaną również mianem elastyczności rynku. Głębokość rynku jest rozumiana jako jego zdolność do absorpcji dość dużych zleceń bez silnego wpływu na cenę. Analizuje się ją zwykle w odniesieniu do poszczególnych instrumentów. Naprężenie rynku odnosi się natomiast do kosztów, jakie musi ponieść inwestor, aby odwrócić pozycję w krótkim czasie. Z kolei sprężystość lub też elastyczność rynku to miara szybkości, z jaką cena powraca do równowagi po losowym i nieinformacyjnym szoku ${ }^{10}$.

Możliwość stworzenia jednego wskaźnika, który byłby w stanie ująć wszystkie wymiary płynności, jest wysoce wątpliwa ${ }^{11}$. Z tego względu w rozważaniach teoretycznych i w badaniach empirycznych można spotkać się z wieloma miarami, które umożliwiają oszacowanie jej poziomu. Prace zawierające przegląd miar płynności oraz analizę poziomu płynności w odniesieniu do polskiego rynku kapitałowego są dostępne w literaturze. Robert Jankowski i Joanna Olbryśs przedstawili mierniki płynności w zależności od tego, który ze wspomnianych wcześniej trzech wymiarów płynności pozwalają one uchwycić. Jako przykład miar głębokości rynku autorzy wymienili m.in.: sumę skumulowanych wolumenów ofert kupna i sprzedaży, średnią skumulowanych wolumenów zleceń kupna i sprzedaży, sumę wartości zleceń kupna i sprzedaży w jednostkach pieniężnych czy średnią wartość zleceń kupna i sprzedaży w jednostkach pieniężnych. Naprężenie jest aproksymowane za pomoca rozpiętości cen kupna i sprzedaży. Pomiar w przypadku sprężystości jest natomiast złożoną kwestią i w zasadzie nie ma jednoznacznej metody, która by to umożliwiała ${ }^{12}$.

Szymon Stereńczak wyróżnił cztery grupy miar. Pierwsza to miary jednowymiarowe. Obejmuje ona miary oparte na kosztach transakcyjnych, do których zalicza się m.in.: spread bid/ask, miernik Rolla oparty na kowariancji zmian cen zamknięcia, zmodyfikowany miernik Rolla czy proporcję dni z zerowym zwrotem. Wskaźniki jednowymiarowe zawierają również miary aktywności inwestorów obrazujące płynność transakcyjną, które są oparte na wolumenie i warto-

10 M. Doman, op. cit.

11 Y. Amihud, op. cit.

12 R. Jankowski, J. Olbryś, Wymiary płynności rynku papierów wartościowych, „Zeszyty Naukowe Uniwersytetu Szczecińskiego. Finanse, Rynki Finansowe, Ubezpieczenia” 2015, nr 73, s. $645-658$. 
ści obrotu. Ich przykładem może być elastyczność obrotu zaproponowana przez Datara, czy miara braku płynności ILLIQ przedstawiona przez Y. Amihuda. Podział zaproponowany przez S. Stereńczaka uwzględnia również miary obliczane na podstawie regresji stóp zwrotu i wielkości obrotu oraz inne miary, których nie można było zaklasyfikować do żadnej z trzech wcześniejszych grup ${ }^{13}$.

Joanna Olbryśs wyodrębniła natomiast dwie grupy miar - miary płynności i miary braku płynności - ich wyższa wartość oznacza bowiem niższą płynność. Do pierwszej z tych grup zaliczyła m.in.: liczbę transakcji, liczbę sprzedanych akcji, wartości sprzedanych akcji, iloraz liczby sprzedanych akcji i akcji wystawionych do sprzedaży, iloraz wartości sprzedanych akcji i akcji wystawionych do sprzedaży, Amivest Liquidity Ratio czy miarę LOT. Druga grupa obejmuje natomiast proporcję dni z zerową stopą zwrotu oraz ILLIQ ${ }^{14}$.

\section{WPLYW PŁYNNOŚCI NA KOSZTY TRANSAKCYJNE I NA STOPĘ ZWROTU Z INWESTYCJI}

Koszty transakcyjne można podzielić na koszty jawne oraz ukryte, co obrazuje schemat 1. Pierwsza z wymienionych kategorii obejmuje koszty, których wysokość jest z góry znana inwestorom, jak np. opłaty i prowizje dla pośredników oraz podatki. Ukryte koszty transakcyjne są natomiast nieobserwowalne i nieznane z wyprzedzeniem. W rzeczywistości to właśnie ten rodzaj kosztów stanowi dominującą część łącznych kosztów transakcyjnych ponoszonych przez inwestorów ${ }^{15}$.

Na koszty ukryte składają się m.in. koszty alternatywne, które można rozumieć jako poniesiona stratę lub zysk utracony przez inwestora w wyniku niewykonania zlecenia lub jego części w trakcie danej sesji giełdowej. Do tej grupy należą również koszty wynikające z ruchu ceny papieru wartościowego w czasie zawierania transakcji, będące wynikiem działania innych podmiotów rynkowych lub rynkowej zmienności cen (ang. timing costs). Można zaliczyć do nich także koszty wynikające z niekorzystnych ruchów cen pojawiajacych się w przypadku, gdy wolumen złożonej transakcji jest zbyt duży. Zjawisko to jest bezpośrednio związane z pojęciem głębokości rynku, a więc jednym z wymiarów płynności ${ }^{16}$, który może być zdefiniowany jako zdolność rynku do absorpcji dość dużych zleceń bez silnego wpływu na cenę ${ }^{17}$. Koszty wynikajace dla inwestora ze wspomnianych ruchów ceny mogą być również zinterpretowane jako koszty natychmiastowego zapotrzebowania na płynność. Poza tym należy

13 S. Stereńczak, Problemy pomiaru ptynności transakcyjnej w kontekście jej wieloaspektowości, „Zeszyty Naukowe Uniwersytetu Szczecińskiego. Finanse, Rynki Finansowe, Ubezpieczenia” 2016, nr 79, s. 125-136.

${ }^{14}$ J. Olbryś, Zastosowanie wybranych miar płynności aktywów kapitałowych na Giełdzie Papierów Wartościowych w Warszawie S.A., 2013, zif.wzr.pl/pim/2013_3_2_5.pdf [dostęp: 22.02.2017].

${ }_{15}$ M. Anson, F. Fabozzi, F. Jones, The Handbook of Traditional and Alternative Investment Vehicles: Investment Characteristics and Strategies, New Jersey 2011.

${ }_{16}$ A. Hachmeister, Informed Traders as Liquidity Providers. Evidence from the German Equity Market, Wiesbaden 2007.

${ }_{17}$ M. Doman, op. cit. 


\section{Schemat 1}

Komponenty kosztów transakcyjnych

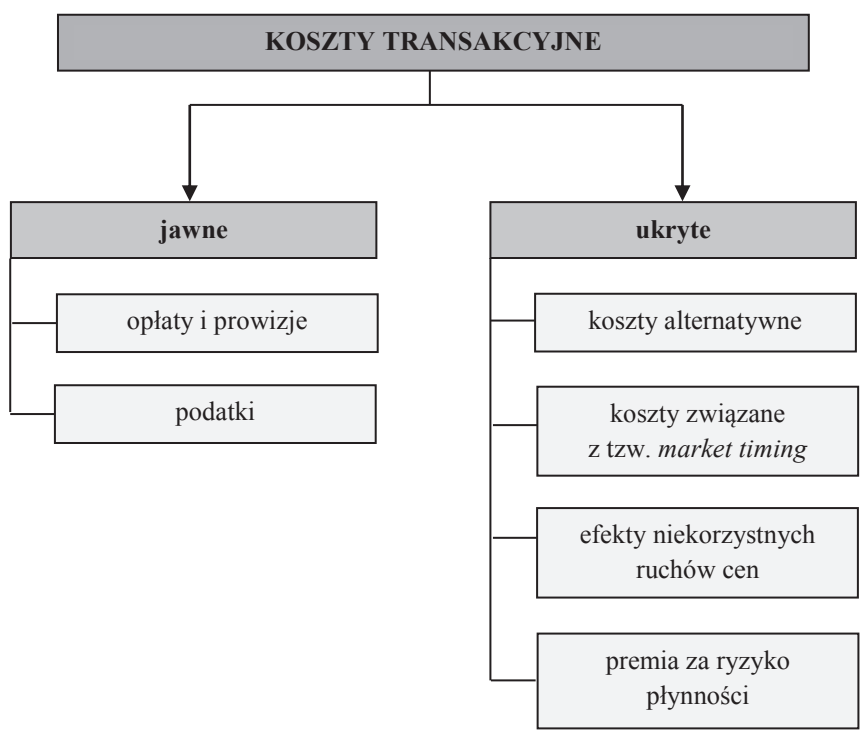

Źródło: opracowanie własne na podstawie P. Gomber, U. Schweickert, Der Market Impact: Liquiditätsmaß im Elektronischen Wertpapierhandel, „Die Bank” 7, 2002, s. 485-489.

wspomnieć o premii za ryzyko płynności ${ }^{18}$. Inwestorzy będą jej oczekiwać w przypadku braku płynności. Liczą się bowiem z potencjalnymi utrudnieniami w odsprzedaży znacznych pakietów akcji po cenie rynkowej. Premia ta powoduje zwiększenie kosztów transakcyjnych - na rynku pierwotnym przejawia się to wyższymi opłatami dla subemitentów lub też niższą sprzedażą akcji, natomiast na rynku wtórnym większą rozpiętością cen kupna i sprzedaży. Płynność oddziałuje więc bezpośrednio na wysokość kosztów transakcyjnych, a przez to na stopę zwrotu z zainwestowanego kapitału i na wycenę spółek, a więc aspekty o fundamentalnym znaczeniu zarówno dla emitentów, jak i dla inwestorów giełdowych ${ }^{19}$.

\section{PODSTAWY METODYCZNE ANALIZY}

\section{Charakterystyka danych wykorzystanych $\mathrm{w}$ badaniu}

Analizie zostały poddane spółki, które zadebiutowały na Giełdzie Papierów Wartościowych w Warszawie przed 2000 r. i były na niej notowane do końca lutego 2017 r. Szeregi czasowe cen akcji, wolumenu obrotu, wartości danej spółki oraz wartości wskaźnika cena do wartości księgowej pochodzą z serwisu

18 A. Hachmeister, op. cit.

19 GPW, Ptynność obrotu, www.gpw.pl/plynnosc_obrotu [dostęp: 20.02.2017]. 
Stooq. Udostępnione na nim szeregi cen są skorygowane o operacje dokonywane na akcjach, takie jak: splity, scalenia, wypłaty dywidend, prawa poboru, czy prawa do akcji. Występowały w nich jednak braki danych.

Z tego względu jeśli w danym dniu dla spółki nie została podana wielkość wolumenu obrotu, usuwano te obserwacje. Wielkość wolumenu obrotu była bowiem niezbędna do obliczenia współczynnika ILLIQ, który przyjęto w badaniu jako miarę płynności. Ponadto ze względu na fakt, że w analizowanym przedziale czasowym w przypadku niektórych spółek zdarzyły się okresy, w których notowania nie odbywały się co najmniej przez miesiąc, zostały one wykluczone z dalszej analizy. Grupa przeanalizowanych spółek składa się z 87 podmiotów. Ponieważ dane dotyczace wartości rynkowej spółek oraz wskaźnika cena do wartości księgowej były dostępne w serwisie Stooq od 2007 r., zakres czasowy badania objął przedział od początku 2008 do końca lutego 2017 r. Są to dane roczne wykorzystane do formowania portfeli w dalszej części analizy. Ponadto do obliczeń zostały wykorzystane obserwacje o częstotliwości miesięcznej, jednakże w zależności od szeregu, wartości pochodzą z końca miesiąca (w przypadku stóp zwrotu spółek i indeksu WIG oraz stopy wolnej od ryzyka) lub stanowia średnią z danego miesiąca (w przypadku współczynnika ILLIQ). Jako stopę wolną od ryzyka przyjęto średnią arytmetyczną stóp bid i ask rocznych bonów skarbowych wyemitowanych w Polsce. Dane te pochodzą z bazy Thomson Reuters.

\section{Miara płynności}

W badaniu empirycznym wykorzystano miarę braku płynności - ILLIQ, zaproponowaną przez Yakova Amihuda w pracy z 2002 r. Jest ona obliczona według poniższego wzoru:

$$
I L L I Q_{i m}=\frac{1}{D_{i m}} \sum_{d=1}^{D_{i m}} \frac{\left|R_{i m d}\right|}{V O L D_{i m d}},
$$

gdzie $R_{\text {imd }}$ to wartość bezwzględna stopy zwrotu odnotowanej przez spółkę $i$ w dniu $d$ miesiąca $m$, to liczba dni, w których odbyły się notowania spółki $i$ w trakcie danego miesiaca $m, D_{i m}$ natomiast $V O L D_{i m d}$ stanowi wyrażoną w PLN wartość wolumenu obrotu akcjami spółki $i$ w dniu $d$, gdzie $d=1,2, \ldots, D_{i m}$. Stosunek ten wyraża bezwzględną zmianę ceny wynikająca z 1 PLN dziennego obrotu. Im wyższa jego wartość, tym mniejsza płynność. W kolejnym kroku dla każdej spółki obliczona została średnia arytmetyczna tego ilorazu w kolejnych miesiącach ${ }^{20}$. Im wyższa wartość wskaźnika, tym mniejsza płynność. Z tego względu może być on zakwalifikowany do grupy miar braku płynności. Jest zaliczany do najbardziej popularnych miar tego typu i uznany za jedna z miar płynności szczególnie użytecznych na rynkach rozwijających się ${ }^{21}$. ILLIQ posiada interpretację, która jest zgodna z intuicyjnym sposobem rozumienia płynnych rynków jako takich, które umożliwiają zawieranie transakcji przy niewielkim wpływie na cenę instrumentów ${ }^{22}$.

${ }^{20}$ Y. Amihud, op. cit.

${ }^{21}$ J. Olbryś, op. cit.

${ }^{22}$ G. A. Karolyi, L. Kuan-Hui, M. A. van Dijk, Understanding commonality in liquidity around the world, „Journal of Financial Economics” 105, 2012, s. 82-112. 
Aby w syntetyczny sposób przedstawić tendencje dla całej próby badawczej, oszacowano wskaźnik AILLIQ. Obliczono go jako średnia arytmetyczną z wartości wskaźnika ILLIQ dla poszczególnych spółek w danym miesiącu. Kształtowanie się wskaźnika AILLIQ zostało przedstawione na wykresie 1.

\section{Wykres 1}

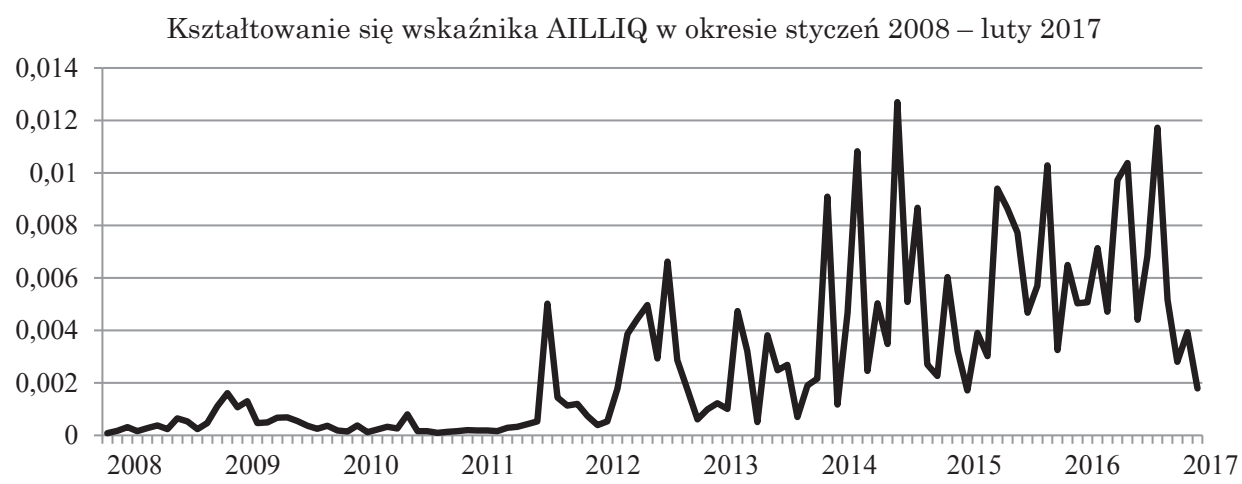

Źródło: opracowanie własne na podstawie danych z serwisu Stooq.

Na wykresie 1 można zauważyć dwa okresy różniące się między sobą poziomem płynności. Pierwszy - od początku próby do końca sierpnia 2011 r. charakteryzował się stosunkowo niskimi wartościami wskaźnika AILLIQ, co oznacza większą płynność. Okres ten pokrywa się ze znacznym spadkiem cen na polskim rynku giełdowym, który był wynikiem globalnego kryzysu finansowego, oraz z następującym po początku 2009 r. odbiciem. Przedstawia to wykres 2, na którym znajduje się kurs zamknięcia indeksu WIG oraz wolumen obrotu akcjami wchodzacymi w jego skład.

\section{Wykres 2}

Kształtowanie się poziomu zamknięcia indeksu WIG (lewa oś) i wolumenu obrotu akcjami wchodzącymi w jego skład (prawa oś) w okresie styczeń 2008 - luty 2017

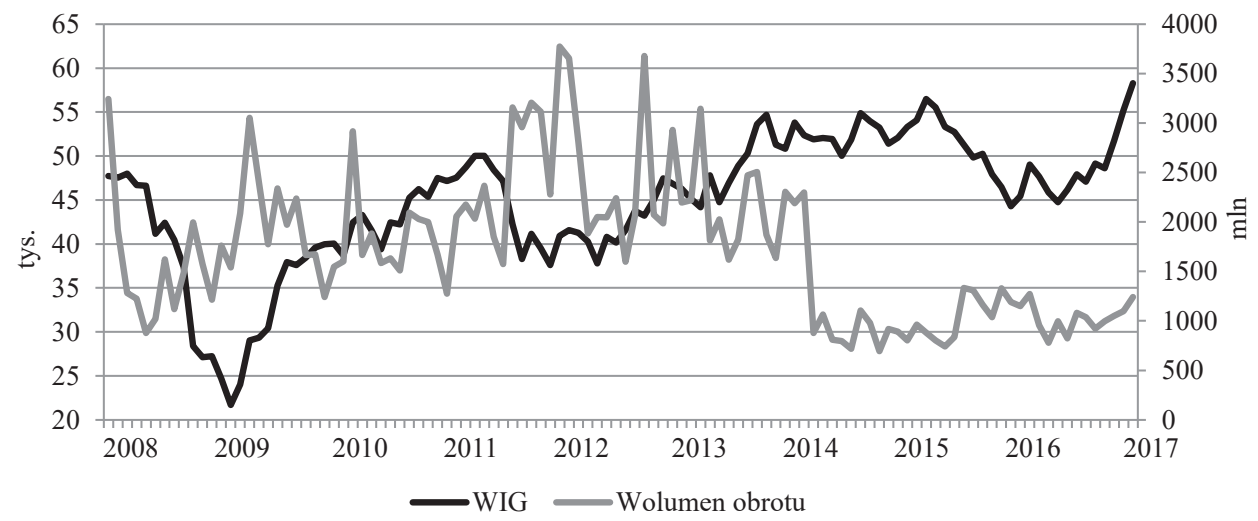

Źródło: opracowanie własne na podstawie danych z serwisu Stooq. 
Wzrost wskaźnika AILLIQ, a więc spadek płynności można zaobserwować od końca 2011 r. Najwyższe wartości wskaźnik ten przyjmował jednak po 2014 r., co może być spowodowane zmianami w polskim systemie emerytalnym, wpływającymi na stopień zaangażowania funduszy inwestycyjnych na polskim parkiecie. Wówczas również AILLIQ podlegał największym fluktuacjom.

\section{Postać wykorzystanego modelu}

Pierwszym etapem analizy było oszacowanie modelu trójczynnikowego, który został zaproponowany przez Famę i Frencha w 1993 r. Wymagało to utworzenia portfeli z analizowanych spółek. Aby to uczynić, wykorzystano procedurę podziału opierającą się na kryterium wielkości spółki (size) oraz stosunku wartości księgowej do wartości rynkowej (book value to market value). W tym celu posłużono się wskaźnikami pobranymi z serwisu Stooq - wartościa rynkową oraz wskaźnikiem cena do wartości księgowej, którego odwrotność wykorzystano, aby obliczyć relację wartości księgowej do wartości rynkowej (BV/MV). Ze względu na dostępność tych wskaźników od 2007, model został oszacowany na podstawie miesięcznych danych z okresu od stycznia 2008 do końca lutego 2017 r. Spółki były sortowane na koniec danego roku odrębnie według każdego z kryteriów, poczynając od 2007 r.

W przypadku wartości rynkowej każdorazowo wyznaczano medianę. Następnie spółki, dla których wartość tego wskaźnika była od niej mniejsza lub jej równa, klasyfikowano jako spółki małe (small), a te o wartości przewyższającej medianę - jako duże (big). Na podstawie wskaźnika BV/MV wyodrębniono trzy grupy spółek - spółki wartościowe (high - to spółki powyżej 70 percentyla), wzrostowe (low - spółki poniżej 30 percentyla) oraz pozostałe, znajdujące się pomiędzy 30 a 70 percentylem (medium). Na podstawie tych kryteriów utworzono 6 rozłącznych portfeli, które były co roku przeformowywane.

W poszczególnych miesiącach analizowanego okresu dla każdego z portfeli obliczono średnią arytmetyczną miesięcznych stóp zwrotu odnotowanych przez spółki zaliczane w danym roku do określonego portfela. Następnie, na podstawie uzyskanych wartości obliczono średnie arytmetyczne dla portfeli:

- S-L, S-M oraz S-H, uzyskujac zmienną small;

- B-L, B-M oraz B-H, uzyskując zmienną big;

- S-H i B-H, uzyskując zmienną high;

- S-L i B-L, uzyskując zmienną low.

W kolejnym kroku stworzono dwie zmienne objaśniające wykorzystane w modelu. Pierwszą z nich jest SMB (small minus big). Powstała ona jako różnica zmiennej small i big. Druga - zmienna HML (high minus low) obliczona przez odjęcie obserwacji zmiennej low od obserwacji zmiennej high.

Powstałe w omówiony powyżej sposób zmienne włączono do modelu, który przyją postać:

$$
r_{p t}-r_{f t}=\alpha_{p}+\beta_{p}\left(r_{M t}-r_{f t}\right)+\beta_{S M B, p} S M B_{t}+\beta_{H M L, p} H M L_{t}+\varepsilon_{p t} .
$$


W modelu tym zmienną objaśniana $-r_{p t}-r_{f t}$ jest nadwyżkowa stopa zwrotu obliczona jako różnica stopy zwrotu z portfela i stopy wolnej od ryzyka. Fama i French stworzyli 25 portfeli wyodrębnionych na podstawie wartości rynkowej oraz wartości wskaźnika BV/MV ${ }^{23}$. Ze względu na liczbę spółek wchodzących w skład próby badawczej liczbę portfeli ograniczono do 6 i jako stopy zwrotu z poszczególnych portfeli wchodzące w skład zmiennych objaśnianych wykorzystano portfele S-L, S-M, S-H, B-L, B-M oraz B-H utworzone do oszacowania zmiennych SMB i HML.

Jako stopę wolną od ryzyka $-r_{f t} \mathrm{w}$ modelu przyjęto wyrażone w ujęciu miesięcznym oprocentowanie rocznych polskich bonów skarbowych. Dane te stanowią średnią arytmetyczną stopy bid oraz stopy ask. Natomiast jako stopę z portfela rynkowego $-r_{M t}$, wykorzystano miesięczne stopy zwrotu z indeksu WIG.

Zmienne objaśniane modelu (2) są ze sobą skorelowane w stopniu słabym lub umiarkowanym, o czym świadczą współczynniki korelacji liniowej Pearsona zawarte w tabeli 1 . Z tego względu możliwe było oszacowanie parametrów modelu.

\section{Tabela 1}

Macierz korelacji zawierająca współczynniki korelacji liniowej Pearsona dla zmiennych objaśniających w modelu dla okresu od stycznia 2008 do lutego 2017

\begin{tabular}{|c|c|c|c|}
\cline { 2 - 4 } \multicolumn{1}{c|}{} & SMB & HML & $\boldsymbol{r}_{\boldsymbol{M t}}-\boldsymbol{r}_{f t}$ \\
\hline SMB & 1,000 & $-0,221$ & $-0,136$ \\
\hline HML & $-0,221$ & 1,000 & 0,351 \\
\hline$r_{M t}-r_{f t}$ & $-0,136$ & 0,351 & 1,000 \\
\hline
\end{tabular}

Źródło: opracowanie własne na podstawie danych z serwisu Stooq i bazy Thomson Reuters.

Etapem badania następującym po oszacowaniu parametrów trójczynnikowego modelu Famy i Frencha dla całego analizowanego okresu było wprowadzenie do modelu miary płynności. Ze względu na kształtowanie się wskaźnika AILLIQ - niskie wartości w pierwszej połowie analizowanego okresu oraz stosunkowo wysokie i zróżnicowane w drugiej, próbę podzielono na dwa podokresy. Pierwszy objął przedział od początku 2008 r. do końca sierpnia 2011 r., natomiast drugi - od września 2011 r. do końca lutego 2017 r. Ponadto oszacowania testu KPSS zaprezentowane w tabeli 2 pozwalają wnioskować, że w przypadku drugiej podpróby, na poziomie istotności 0,05, należy odrzucić hipotezę zerową testu zakładającą stacjonarność szeregu. Z tego względu we wszystkich obliczeniach posłużono się pierwszymi przyrostami wartości wskaźnika, które w obu podpróbach można uznać za stacjonarne.

${ }^{23}$ E. Fama, K. French, Common risk factors in the returns on stock and bonds, „Journal of Financial Economics" 33, 1993, s. 3-56. 
Tabela 2

Wyniki testu KPSS dla obu podprób

\begin{tabular}{|l|c|c|c|c|}
\cline { 2 - 4 } \multicolumn{1}{c|}{} & \multicolumn{2}{c|}{ I podpróba } & \multicolumn{2}{c|}{ II podpróba } \\
\cline { 2 - 4 } & $\begin{array}{c}\text { Wart. stat. } \\
\text { testowej }\end{array}$ & $\begin{array}{c}\text { Wart. kryt. } \\
\text { dla } \boldsymbol{a}=\mathbf{0 , 5}\end{array}$ & $\begin{array}{c}\text { Wart. stat. } \\
\text { testowej }\end{array}$ & $\begin{array}{c}\text { Wart. kryt. } \\
\text { dla } \boldsymbol{a}=\mathbf{0 , 5}\end{array}$ \\
\hline AILLIQ & 0,270 & \multirow{2}{*}{0,462} & 0,925 & \multirow{2}{*}{0,462} \\
\cline { 1 - 2 } przyrost AILLIQ & 0,090 & & 0,077 & \\
\hline
\end{tabular}

Źródło: opracowanie własne na podstawie danych z serwisu Stooq i bazy Thomson Reuters.

\section{WYNIKI BADANIA}

Oszacowania parametrów trójczynnikowego modelu Famy i Frencha przedstawiono $\mathrm{w}$ tabeli 3 . W nawiasach zostały podane błędy standardowe, a wytłuszczono oszacowania, które są statystycznie istotnie różne od zera na poziomie istotności 0,05 .

Tabela 3

Oszacowania współczynników trójczynnikowego modelu Famy i Frencha w okresie styczeń 2008 - luty 2017

\begin{tabular}{|c|c|c|c|c|c|c|}
\hline & SMB & HML & $r_{M t}-r_{f t}$ & const & $R^{2}$ & skoryg. $R^{2}$ \\
\hline S-L & $\begin{array}{c}0,928 \\
(0,130)\end{array}$ & $\begin{array}{l}-0,435 \\
(0,111)\end{array}$ & $\begin{array}{c}1,040 \\
(0,072)\end{array}$ & $\begin{array}{l}-0,003 \\
(0,004)\end{array}$ & 0,698 & 0,688 \\
\hline S-M & $\begin{array}{c}0,853 \\
(0,125)\end{array}$ & $\begin{array}{c}0,302 \\
(0,106)\end{array}$ & $\begin{array}{c}0,988 \\
(0,070)\end{array}$ & $\begin{array}{l}-0,008 \\
(0,004)\end{array}$ & 0,728 & 0,719 \\
\hline S-H & $\begin{array}{c}0,992 \\
(0,079)\end{array}$ & $\begin{array}{c}0,754 \\
(0,067)\end{array}$ & $\begin{array}{c}0,955 \\
(0,044)\end{array}$ & $\begin{array}{c}-0,005 \\
(0,003)\end{array}$ & 0,895 & 0,892 \\
\hline B-L & $\begin{array}{l}-0,053 \\
(0,076)\end{array}$ & $\begin{array}{l}-0,186 \\
(0,065)\end{array}$ & $\begin{array}{c}0,945 \\
(0,042)\end{array}$ & $\begin{array}{l}-0,006 \\
(0,002)\end{array}$ & 0,834 & 0,828 \\
\hline B-M & $\begin{array}{l}-0,057 \\
(0,120 \\
0,119)\end{array}$ & $\begin{array}{c}0,181 \\
(0,102 ; \\
0,131)\end{array}$ & $\begin{array}{c}1,008 \\
(0,067 \\
0,059)\end{array}$ & $\begin{array}{l}-0,006 \\
(0,004 \\
0,005)\end{array}$ & 0,731 & 0,722 \\
\hline B-H & $\begin{array}{l}-0,117 \\
(0,124)\end{array}$ & $\begin{array}{c}0,625 \\
(0,106)\end{array}$ & $\begin{array}{c}1,030 \\
(0,069)\end{array}$ & $\begin{array}{l}-0,004 \\
(0,004)\end{array}$ & 0,780 & 0,773 \\
\hline
\end{tabular}

Źródło: opracowanie własne na podstawie danych z serwisu Stooq i bazy Thomson Reuters.

Parametrem, który zwykle wywierał największy wpływ na kształtowanie się nadwyżkowych stóp zwrotu z portfeli, była rynkowa nadwyżkowa stopa zwrotu. Oddziaływała ona w statystycznie istotny sposób w przypadku wszystkich analizowanych portfeli. Silny, dodatni wpływ na spółki małe wywierała 
zmienna SMB. W przypadku spółek dużych okazała się ona statystycznie nieistotna. Wyniki te wskazują na występowanie anomalii rynkowej znanej jako efekt małych spółek, co oznacza, że inwestycje w spółki o niskiej kapitalizacji mogły przynieść ponadprzeciętne stopy zwrotu. Należy jednak zaznaczyć, że analiza została oparta na spółkach, które były nieprzerwanie notowane na giełdzie od 2000 do 2017 r. Nie uwzględniono więc tych podmiotów, które w tym czasie przestały być notowane na parkiecie. Z tego względu na wyniki mógł mieć w pewnym stopniu wpływ tzw. efekt przeżywalności (ang. survivirship bias). Niemniej jednak podobne wnioski można spotkać w literaturze - również L. Czapiewski zauważył, że portfele złożone z mniejszych spółek przynoszą wyższe nadwyżkowe stopy zwrotu w porównaniu z portfelami zawierajacymi spółki większe ${ }^{24}$.

Zmienna HML wywierała natomiast ujemny wpływ na spółki o niskim stosunku wartości księgowej do rynkowej - spółki wzrostowe oraz dodatni wpływ na spółki dochodowe, a więc te o wysokich wartościach tego wskaźnika. Inwestycje w spółki dochodowe przynosiły więc wyższe stopy zwrotu niż inwestycje w spółki wzrostowe. Warto również zauważyć, że trójczynnikowy model Famy i Frencha stosunkowo dobrze opisał zmienność nadwyżkowych stóp zwrotu z portfeli, współczynnik determinacji zawarł się bowiem w przedziale od 70 do 90\%.

Kolejnym etapem analizy było przeprowadzenie testów diagnostycznych na resztach z modeli. Ich wyniki zostały zestawione w tabeli 4 . Do oceny normalności rozkładu wykorzystano test Doornika-Hansena. Jego hipoteza zerowa zakłada, że reszty mają rozkład normalny. W celu oceny jednorodności wariancji składnika resztowego posłużono się testem White’a, którego hipoteza zerowa zakłada brak heteroskedastyczności. Z kolei by sprawdzić, czy szeregi reszt charakteryzują się istotną autokorelacja, posłużono się testem Durbina-Watsona. W tym przypadku testowana hipoteza zakłada brak autokorelacji reszt.

Tabela 4

Wyniki testów Doornika-Hansena, White'a i Durbina-Watsona dla reszt z modeli trójczynnikowych dla okresu od stycznia 2008 do lutego 2017 (wartości p)

\begin{tabular}{|c|c|c|c|}
\hline $\begin{array}{c}\text { Zmienna } \\
\text { objaśniana modelu }\end{array}$ & $\begin{array}{c}\text { Test } \\
\text { Doornika-Hansena }\end{array}$ & $\begin{array}{c}\text { Test } \\
\text { White'a }\end{array}$ & $\begin{array}{c}\text { Test } \\
\text { Durbina-Watsona }\end{array}$ \\
\hline S-L & $\mathbf{0 , 0 0 8 0 1}$ & 0,27126 & 0,22172 \\
\hline S-M & 0,32749 & 0,15589 & 0,24561 \\
\hline S-H & 0,22755 & 0,97248 & 0,38827 \\
\hline B-L & $\mathbf{0 , 0 0 7 0 7}$ & 0,82844 & 0,20239 \\
\hline B-M & $\mathbf{0 , 0 0 4 2 1}$ & $\mathbf{0 , 0 3 7 3 8}$ & 0,53987 \\
\hline B-H & 0,18580 & 0,18235 & 0,08298 \\
\hline
\end{tabular}

Źródło: opracowanie własne na podstawie danych z serwisu Stooq i bazy Thomson Reuters.

${ }^{24}$ L. Czapiewski, Wykorzystanie..., passim. 
Podstawy do odrzucenia hipotezy zerowej na rzecz alternatywnej na poziomie istotności równym 0,05 wystapiły w przypadku testu Doornika-Hansena dla modeli, w których zmienną objaśnianą była nadwyżkowa stopa zwrotu z portfela S-L, B-L oraz B-M oraz w przypadku testu White'a dla tego ostatniego modelu. Rozkład reszt $\mathrm{z}$ tych modeli odbiega więc od rozkładu normalnego, a w przypadku modelu, w którym zmienną objaśnianą była nadwyżkowa stopa zwrotu z portfela B-M, występuje dodatkowo heteroskedastyczność. Z tego względu dla tego modelu obliczono również błędy standardowe odporne na autokorelację i heteroskedastyczność. Zostały one podane w odpowiednich komórkach tabeli 3, jako druga wartość w nawiasach. Zmiana metody obliczania błędów nie wpłynęła jednak na wnioski dotyczące istotności oszacowań parametrów tego modelu.

Tabela 5

Oszacowania współczynników trójczynnikowego modelu Famy i Frencha w podpróbach

\begin{tabular}{|c|c|c|c|c|c|c|c|}
\hline & $\begin{array}{c}\text { przyrost } \\
\text { AILLIQ }\end{array}$ & SMB & HML & $r_{M t}-r_{f t}$ & const & $\mathbf{R}^{2}$ & skoryg. $\mathbf{R}^{2}$ \\
\hline \multicolumn{8}{|c|}{ I podpróba - styczeń 2008 - sierpień 2011} \\
\hline S-L & - & $\begin{array}{c}0,870 \\
(0,20 ; 0,18)\end{array}$ & $\begin{array}{c}-0,389 \\
(0,16 ; 0,12)\end{array}$ & $\begin{array}{c}0,975 \\
(0,09 ; 0,08)\end{array}$ & $\begin{array}{c}-0,003 \\
(0,01 ; 0,01)\end{array}$ & 0,784 & 0,768 \\
\hline S-M & - & $\begin{array}{c}1,112 \\
(0,186)\end{array}$ & $\begin{array}{c}0,336 \\
(0,149)\end{array}$ & $\begin{array}{c}1,047 \\
(0,081)\end{array}$ & $\begin{array}{c}-0,017 \\
(0,007)\end{array}$ & 0,870 & 0,860 \\
\hline S-H & - & $\begin{array}{c}0,899 \\
(0,107)\end{array}$ & $\begin{array}{c}0,869 \\
(0,085)\end{array}$ & $\begin{array}{c}0,939 \\
(0,046)\end{array}$ & $\begin{array}{c}-0,012 \\
(0,004)\end{array}$ & 0,958 & 0,955 \\
\hline B-L & - & $\begin{array}{l}-0,113 \\
(0,116)\end{array}$ & $\begin{array}{l}-0,112 \\
(0,093)\end{array}$ & $\begin{array}{c}0,954 \\
(0,051)\end{array}$ & $\begin{array}{c}-0,013 \\
(0,004)\end{array}$ & 0,916 & 0,910 \\
\hline B-M & - & $\begin{array}{c}0,136 \\
(0,16 ; 0,13)\end{array}$ & $\begin{array}{l}0,298 \\
(0,13 ; \\
0,14)\end{array}$ & $\begin{array}{l}1,018 \\
(\mathbf{0}, 07 \\
\mathbf{0 , 0 6 )}\end{array}$ & $\begin{array}{l}-0,015 \\
(0,01 ; \\
0,004)\end{array}$ & 0,888 & 0,880 \\
\hline B-H & - & $\begin{array}{c}-0,142 \\
(0,20 \\
0,13)\end{array}$ & $\begin{array}{l}0,630 \\
(0,16 ; \\
0,14)\end{array}$ & $\begin{array}{c}0,990 \\
(0,09 \\
0,09)\end{array}$ & $\begin{array}{c}-0,004 \\
(0,01 ; \\
0,01)\end{array}$ & 0,862 & 0,852 \\
\hline \multicolumn{8}{|c|}{ I podpróba - styczeń 2008 - sierpień 2011 z uwzględnieniem miary płynności } \\
\hline S-L & $\begin{array}{c}9,022 \\
(23,194)\end{array}$ & $\begin{array}{c}0,867 \\
(0,201)\end{array}$ & $\begin{array}{c}-0,378 \\
(0,163)\end{array}$ & $\begin{array}{c}0,974 \\
(0,088)\end{array}$ & $\begin{array}{c}-0,004 \\
(0,007)\end{array}$ & 0,785 & 0,783 \\
\hline S-M & $\begin{array}{c}3,953 \\
(21,736)\end{array}$ & $\begin{array}{c}1,110 \\
(0,188)\end{array}$ & $\begin{array}{c}0,341 \\
(0,153)\end{array}$ & $\begin{array}{c}1,046 \\
(0,082)\end{array}$ & $\begin{array}{c}-0,017 \\
(0,007)\end{array}$ & 0,870 & 0,857 \\
\hline S-H & $\begin{array}{c}-3,587 \\
(12,453)\end{array}$ & $\begin{array}{c}0,901 \\
(0,108)\end{array}$ & $\begin{array}{c}0,865 \\
(0,088)\end{array}$ & $\begin{array}{c}0,939 \\
(0,047)\end{array}$ & $\begin{array}{c}-0,012 \\
(0,004)\end{array}$ & 0,958 & 0,954 \\
\hline B-L & $\begin{array}{c}-8,207 \\
(13,542)\end{array}$ & $\begin{array}{l}-0,110 \\
(0,117)\end{array}$ & $\begin{array}{l}-0,122 \\
(0,095)\end{array}$ & $\begin{array}{c}0,954 \\
(0,051)\end{array}$ & $\begin{array}{c}-0,013 \\
(0,004)\end{array}$ & 0,917 & 0,908 \\
\hline B-M & $\begin{array}{c}13,192 \\
(18,638)\end{array}$ & $\begin{array}{c}0,131 \\
(0,161)\end{array}$ & $\begin{array}{c}0,314 \\
(0,131)\end{array}$ & $\begin{array}{c}1,017 \\
(0,070)\end{array}$ & $\begin{array}{c}-0,016 \\
(0,006)\end{array}$ & 0,889 & 0,878 \\
\hline B-H & $\begin{array}{c}4,403 \\
(22,987)\end{array}$ & $\begin{array}{l}-0,144 \\
(0,199)\end{array}$ & $\begin{array}{c}0,635 \\
(0,162)\end{array}$ & $\begin{array}{c}0,989 \\
(0,087)\end{array}$ & $\begin{array}{c}-0,004 \\
(0,007)\end{array}$ & 0,863 & 0,849 \\
\hline
\end{tabular}




\begin{tabular}{|c|c|c|c|c|c|c|c|}
\hline \multicolumn{8}{|c|}{ II podpróba - wrzesień 2011 - luty 2017} \\
\hline S-L & - & $\begin{array}{c}0,963 \\
(0,178) \\
\end{array}$ & $\begin{array}{c}-0,485 \\
(0,169) \\
\end{array}$ & $\begin{array}{c}1,183 \\
(0,137) \\
\end{array}$ & $\begin{array}{r}-0,005 \\
(0,006) \\
\end{array}$ & 0,625 & 0,601 \\
\hline S-M & - & $\begin{array}{c}0,704 \\
(0,161) \\
\end{array}$ & $\begin{array}{c}0,370 \\
(0,153) \\
\end{array}$ & $\begin{array}{c}0,770 \\
(0,124) \\
\end{array}$ & $\begin{array}{c}-0,001 \\
(0,005) \\
\end{array}$ & 0,504 & 0,473 \\
\hline S-H & - & $\begin{array}{c}1,029 \\
(0,112) \\
\end{array}$ & $\begin{array}{c}0,721 \\
(0,106) \\
\end{array}$ & $\begin{array}{c}0,908 \\
(0,086) \\
\end{array}$ & $\begin{array}{c}-0,002 \\
(0,004)\end{array}$ & 0,794 & 0,781 \\
\hline B-L & - & $\begin{array}{c}-0,025 \\
(0,100)\end{array}$ & $\begin{array}{c}-0,170 \\
(0,095)\end{array}$ & $\begin{array}{c}0,849 \\
(0,077)\end{array}$ & $\begin{array}{c}-0,002 \\
(0,003)\end{array}$ & 0,667 & 0,646 \\
\hline B-M & - & $\begin{array}{c}-0,189 \\
(0,169)\end{array}$ & $\begin{array}{c}0,152 \\
(0,160)\end{array}$ & $\begin{array}{c}0,890 \\
(0,130)\end{array}$ & $\begin{array}{c}-0,002 \\
(0,005)\end{array}$ & 0,500 & 0,469 \\
\hline B-H & - & $\begin{array}{c}-0,091 \\
(0,168)\end{array}$ & $\begin{array}{c}0,624 \\
(0,159)\end{array}$ & $\begin{array}{c}1,123 \\
(0,129)\end{array}$ & $\begin{array}{c}-0,004 \\
(0,005)\end{array}$ & 0,676 & 0,655 \\
\hline \multicolumn{8}{|c|}{ II podpróba - wrzesień 2011 - luty 2017 z uwzględnieniem miary płynności } \\
\hline S-L & $\begin{array}{c}-1,160 \\
(1,570)\end{array}$ & $\begin{array}{c}0,965 \\
(0,179)\end{array}$ & $\begin{array}{c}-0,475 \\
(0,170)\end{array}$ & $\begin{array}{c}1,160 \\
(0,141)\end{array}$ & $\begin{array}{c}-0,004 \\
(0,006)\end{array}$ & 0,628 & 0,597 \\
\hline S-M & $\begin{array}{c}-0,391 \\
(1,428)\end{array}$ & $\begin{array}{c}0,705 \\
(0,163)\end{array}$ & $\begin{array}{c}0,705 \\
(0,163)\end{array}$ & $\begin{array}{c}0,763 \\
(0,128)\end{array}$ & $\begin{array}{c}-0,001 \\
(0,005)\end{array}$ & 0,504 & 0,462 \\
\hline S-H & $\begin{array}{c}-1,708 \\
(0,965)\end{array}$ & $\begin{array}{c}1,033 \\
(0,110)\end{array}$ & $\begin{array}{c}0,736 \\
(0,104)\end{array}$ & $\begin{array}{c}0,876 \\
(0,087)\end{array}$ & $\begin{array}{c}-0,002 \\
(0,004)\end{array}$ & 0,804 & 0,787 \\
\hline B-L & $\begin{array}{c}-1,302 \\
(0,872)\end{array}$ & $\begin{array}{c}-0,021 \\
(0,099)\end{array}$ & $\begin{array}{c}-0,159 \\
(0,094)\end{array}$ & $\begin{array}{c}0,824 \\
(0,078)\end{array}$ & $\begin{array}{l}-0,001 \\
(0,003)\end{array}$ & 0,679 & 0,651 \\
\hline B-M & $\begin{array}{c}-1,202 \\
(1,489)\end{array}$ & $\begin{array}{c}-0,186 \\
(0,170)\end{array}$ & $\begin{array}{c}0,163 \\
(0,161)\end{array}$ & $\begin{array}{c}0,866 \\
(0,134)\end{array}$ & $\begin{array}{c}-0,002 \\
(0,005)\end{array}$ & 0,505 & 0,463 \\
\hline B-H & $\begin{array}{c}-0,754 \\
(1,482)\end{array}$ & $\begin{array}{c}-0,089 \\
(0,169)\end{array}$ & $\begin{array}{c}0,630 \\
(0,160)\end{array}$ & $\begin{array}{c}1,109 \\
(0,133)\end{array}$ & $\begin{array}{c}-0,004 \\
(0,005)\end{array}$ & 0,677 & 0,649 \\
\hline
\end{tabular}

Źródło: opracowanie własne na podstawie danych z serwisu Stooq i bazy Thomson Reuters.

Następnie oszacowano parametry modeli - parametry trójczynnikowego modelu Famy i Frencha oraz modelu uwzględniającego dodatkową zmienną objaśniająca $\mathrm{w}$ postaci miary płynności, w dwóch wyodrębnionych podokresach. Wyniki zostały zawarte $\mathrm{w}$ tabeli 5. Oszacowanie parametru stojącego przy przyrostach zmiennej AILLIQ nie okazało się statystycznie istotnie różne od zera w żadnym z przypadków.

W kolejnym kroku dla reszt z modeli trójczynnikowych przeprowadzono omówione wcześniej testy diagnostyczne - test Doornika-Hansena, test White'a oraz test Durbina-Watsona. Wyniki tych testów zostały zawarte w tabeli 6 . Na poziomie istotności 0,05 można stwierdzić, że w pierwszej podpróbie składniki losowe modelu, w którym zmienną objaśnianą były nadwyżkowe stopy zwrotu z portfela B-M charakteryzują się heteroskedastycznościa, a składniki losowe modeli, w których zmiennymi zależnymi były nadwyżkowe stopy zwrotu z portfeli S-L i B-H autokorelacja. Z tego względu dla tych modeli obliczono również błędy standardowe odporne na autokorelację i heteroskedastyczność. Zostały one podane w odpowiednich komórkach tabeli 5, jako druga wartość w nawiasach. Zmiana metody obliczania błędów nie wpłynęła jednak na wnioski dotyczące istotności oszacowań parametrów modeli. 
Tabela 6

Wyniki testów Doornika-Hansena, White'a i Durbina-Watsona dla reszt z modeli trójczynnikowych dla dwóch podprób (wartości $p$ )

\begin{tabular}{|c|c|c|c|}
\hline $\begin{array}{c}\text { Zmienna } \\
\text { objaśniana modelu }\end{array}$ & $\begin{array}{c}\text { Test } \\
\text { Doornika-Hansena }\end{array}$ & $\begin{array}{c}\text { Test } \\
\text { White'a }\end{array}$ & $\begin{array}{c}\text { Test } \\
\text { Durbina-Watsona }\end{array}$ \\
\hline \multicolumn{4}{|c|}{ I podpróba - styczeń $\mathbf{2 0 0 8}$ - sierpień 2011 } \\
\hline S-L & 0,71156 & 0,20176 & $\mathbf{0 , 0 2 0 6 1}$ \\
\hline S-M & 0,59730 & 0,27149 & 0,45249 \\
\hline S-H & 0,28095 & 0,54903 & 0,07419 \\
\hline B-L & 0,22741 & 0,86963 & 0,09307 \\
\hline B-M & $\mathbf{0 , 0 4 7 7 3}$ & $\mathbf{0 , 0 0 5 5 1}$ & 0,48407 \\
\hline B-H & 0,89065 & 0,63063 & $\mathbf{0 , 0 2 3 9 0}$ \\
\hline & II podpróba- wrzesień $\mathbf{2 0 1 1 - l u t y ~ 2 0 1 7}$ \\
\hline S-L & $\mathbf{0 , 0 0 1 4 0}$ & 0,66062 & 0,47793 \\
\hline S-M & 0,11340 & 0,25094 & 0,40814 \\
\hline S-H & 0,30872 & 0,92037 & 0,63669 \\
\hline B-L & $\mathbf{0 , 0 4 1 8 9}$ & 0,08421 & 0,64581 \\
\hline B-M & $\mathbf{0 , 0 2 7 9 9}$ & 0,17924 & 0,57791 \\
\hline B-H & 0,07882 & 0,59967 & 0,27418 \\
\hline
\end{tabular}

Źródło: opracowanie własne na podstawie danych z serwisu Stooq i bazy Thomson Reuters.

\section{PODSUMOWANIE}

Płynność instrumentów finansowych jest pojęciem kluczowym zarówno z perspektywy pojedynczego inwestora, jak i całego rynku kapitałowego. Ze względu na swoje powiązanie z kosztami transakcyjnymi płynność jest jednym z czynników kształtujących zysk z inwestycji osiagany przez inwestorów. Przez oddziaływanie na wysokość oczekiwanego zwrotu z inwestycji wpływa na koszt pozyskiwania kapitału przez spółki i na alokację zasobów w sferze gospodarki realnej.

W artykule przedstawiono próbę weryfikacji hipotezy zakładającej, że poziom płynności ma znaczenie przy wycenie spółek na Giełdzie Papierów Wartościowych w Warszawie. Pierwszym etapem analizy było oszacowanie parametrów trójczynnikowego modelu Famy i Frencha, który dobrze dopasował się do danych z okresu 2008-2017 i pozwolił na wychwycenie takich anomalii rynkowych, jak efekt wielkości czy osiaganie ponadprzeciętnych stóp zwrotu przez spółki dochodowe. Następnie zmodyfikowano ten model, wprowadzając do niego dodatkowa zmienna objaśniająca, którą była średnia arytmetyczna z wartości wskaźnika ILLIQ dla poszczególnych spółek, stanowiąca syntetyczną miarę płynności dla całej próby badawczej. Wykorzystana miara płynności nie okazała się istotnym czynnikiem wyjaśniającym zmienność stóp zwrotu na polskiej giełdzie. Zmienne niezależne uwzględnione w modelu Famy i Frencha wyjaśniły dużą część zmienności stóp zwrotu, natomiast dodanie wybranej miary płynności nie wniosło do 
niego nowej informacji. Rynek polski może być zbyt mało płynny, aby czynnik ten miał istotny wpływ na nadwyżkową stopę zwrotu z inwestycji. Identyfikacja pozostałych czynników wyjaśniających zmienność nadwyżkowej stopy zwrotu może być jednym z kierunków dalszych badań. Ponadto mając w pamięci fakt, że płynność jest pojęciem niezwykle złożonym i wielowymiarowym, oraz to, że nie ma jednej miary, która byłaby w stanie uchwycić wszystkie jej aspekty, wykorzystanie innych miar płynności do weryfikacji przyjętej w artykule hipotezy może stanowić asumpt do dalszych analiz.

mgr Katarzyna Wtosik

Uniwersytet Ekonomiczny w Poznaniu

katarzyna.wlosik@ue.poznan.pl

\section{LIQUIDITY IN STOCK PRICING ON THE WARSAW STOCK EXCHANGE}

\section{Summary}

The main objective of this article is to verify the assumption that the level of liquidity does matter in stock pricing on the Warsaw Stock Exchange. The ILLIQ introduced by Yakov Amihud in a paper published in 2002 was selected as the measure of liquidity. It is calculated by dividing the absolute return on the stock of a given company on a particular day by the volume expressed in selected currency on the same day. This measure was used as an additional independent variable in the Fama and French three factor model. The analysis was based on the monthly data for 87 stocks from January 2008 to the end of February 2017. The results showed that in the analysed period small-cap stocks outperformed large-cap stocks and value stocks generated higher returns than growth stocks. The additional measure of liquidity turned out to be statistically insignificant. 
